\title{
A Study of the Impact of Death Receptor 4 (DR4) Gene Polymorphisms in Alzheimer's Disease
}

\author{
Tuba Gökdoğan Edgünlü1, Aynur Özge ${ }^{2}$, Osman Özgür Yalın², Seval Kul ${ }^{3}$, Mehmet Emin Erdal ${ }^{4}$ \\ ${ }^{1}$ Muğla School of Health Sciences, Muğla, Turkey \\ ${ }^{2}$ Department of Neurology, Mersin University School of Medicine, Mersin, Turkey \\ ${ }^{3}$ Department of Biostatistics, Gaziantep University School of Medicine, Gaziantep, Turkey \\ ${ }^{4}$ Department of Medical Biology and Genetics, Mersin University School of Medicine, Mersin, Turkey
}

\begin{abstract}
Background: Excessive apoptosis is believed to play a role in many degenerative and non-degenerative neurological diseases including Alzheimer's disease (AD). Much recent data suggest that apoptotic mechanisms may represent the missing link between $A \beta$ deposition and proteolysis of tau protein. However, there is emerging evidence that apoptotic mechanisms may play a role in Alzheimer's Disease pathogenesis in the absence of overt apoptosis. TNF-related apoptosis inducing ligand receptor 1 (Death Receptor 4, DR4) might impair the apoptotic signal transduction and lead to dysregulation of the homeostasis between cell survival and cell death.
\end{abstract}

Aims: The aim of our study was to further investigate the relationship between genetic variants of DR4 and Alzheimer's Disease.

Study Design: Case control study.

Methods: Sixty-eight patients with AD were included in the study. The control group comprised 72 subjects without signs of neurodegenerative diseases, as evidenced by the examination.DNA was extracted from whole blood using the salting-out procedure. Genotypes were identified by restriction fragment length polymorphism analysis of polymerase chain reaction (PCR-RFLP) products.

Results: We observed significant differences in the genotypic distribution of the rs 6557634 polymorphism in $A D$ patients compared with controls ( $<<0.05)$; our data suggest that the GA genotype in rs 6557634 could be protective against $A D(p<0.05)$. However, there were no significant differences between $A D$ patients and control groups in terms of the DR4 rs20575 polymorphism ( $p>0.05$ ) and the DR4 rs20576 polymorphism ( $>>0.05)$. According to haplotype analysis of the DR4 gene for rs6557634, rs20575 and rs20576 polymorphisms, GCA and GCC haplotypes might be a risk factor for AD. Also, we have shown that ACA, GGC and GGA haplotypes might be protective factors against $A D$.

Conclusion: The present results indicate for the first time the possible contribution of the DR4 gene rs6557634, rs20575, rs20576 polymorphisms in Alzheimer's Disease, which may influence susceptibility to Alzheimer's Disease.

Key Words: Alzheimer's disease, death receptor 4, genetic polymorphism

Received: 07.08.2012

Accepted: 07.04.2013

\section{Introduction}

Alzheimer's disease is a major public health issue; the prevalence of dementia is believed to range from $6 \%$ to $10 \%$ in adults aged 65 years and older, with approximately two thirds of the cases being Alzheimer's disease (1). Histopathological studies showed classical hallmarks including neurofibrillary tangles, senile plaques and extensive neuronal loss in different brain regions of the neocortex and hippocampus regions of the neocortex and hippocampus $(2,3)$. Alzheimer's disease is thought to be a multifactorial disease, probably caused by complicated interactions between genetic and environmental factors. Alzheimer's disease is neuropathologically characterised by a loss of synapses, extracellular deposition of amyloid b-protein (Ab), intracellular formation of neurofibrillary tangles and neuronal cell death (4).

Apoptosis (also called programmed cell death) occurs naturally under normal physiological conditions and in a variety of diseases, while necrosis is caused by external factors, such as infection, toxins, or trauma. Apoptosis is a fea- ture of both acute and chronic central nervous system neurodegenerative diseases (5).

Death receptors are cell surface receptors that transmit apoptotic signals initiated by specific ligands such as Fas ligand, Tumor Necrosis Factor alpha (TNF alpha) and TNF-related apoptosis inducing ligand (TRAIL). They play an important role in apoptosis and can activate a caspase cascade within seconds of ligand binding. The induction of apoptosis via this mechanism is therefore very rapid. Binding of TRAIL to its receptors DR4 or DR5 triggers rapid apoptosis in many cells. Interestingly, there are also decoy receptors that compete for the binding of TRAIL with the DR4 and DR5 receptors. The death receptors for TRAIL, DR4 and DR5, contain cysteine rich repeats in the extracellular domain that bind to TRAIL causing receptor trimerisation and subsequent apoptosis $(6,7)$. There is evidence suggesting that caspases play a role in Alzheimer's disease, Parkinson's disease, and dementia associated with Human Immunodeficiency Virus infection (8-10).

Although TRAIL is not normally expressed in the CNS, it is possible that, in neurodegenerative diseases, TRAIL is ex- 
pressed on macrophages, which may infiltrate into the brain. Those macrophages may interact with different cell types in the CNS that possess TRAIL receptors causing cell injury or death. Alternatively, cells in the CNS are capable of producing TRAIL upon induction by immune activation, such as IFN- $\gamma$ or other pathogens; those cells include neurons, microglia and astrocytes $(11,12)$. Recently, Cantarella et al. reported that neutralisation of the TRAIL death pathway protected a human neuronal cell line from $\beta$-amyloid toxicity. This is the first paper reporting the possible involvement of the TRAIL pathway in neurodegenerative processes in AD (13). However, the contribution of death receptor-initiated apoptosis in Alzheimer's disease remains to be firmly established $(14,15)$. Induced TRAIL may then cause apoptosis of brain cells. Post-mortem pathological examination showed that TRAIL is expressed in AD brains (3, 16). However, there is conflicting evidence about the frequency and role of DR4 gene polymorphisms in AD pathogenesis.

The aim of this study was the investigation of DR4 gene polymorphisms in $A D$; therefore, we determined the frequency of three polymorphisms in DR4, namely G422A (rs6557634), C626G (rs20575) A683C (rs20576), in AD.

\section{Material and Methods}

We used PCR-RFLP methods for the determination of DR4 gene polymorphisms in AD patients and controls. For this reason, ethical consent was taken from the regional ethical committee and procedures were performed according to the principles of The Helsinki Declaration.

\section{Participants}

We evaluated 68 consecutive Alzheimer's patients (30 women, 38 men; mean age 73.5 \pm 10 years) from the database of Mersin University Medical Faculty, Department of Neurology. Seventy-eight (38 women, 40 men; mean age 71.05 \pm 5 years) unrelated, age- and sex-matched, healthy controls (generally healthy spouses, MMSE score>24) were selected from the same geographic area. Patients with $A D$ were wellmatched with controls in terms of age and gender. All AD cases met the National Institute of Neurological and Communicative Disorders and Stroke and the Alzheimer's disease and Related Disorders Association (NINCDS-ADRDA) criteria of probable AD at the end of the study (17). In this study protocol, all subjects underwent a detailed biochemical screen (including thyroid function testing, B12-Folic acid level, malignancy screen, etc.) and radiological investigation (Cranial CT or MRI, according to patient) before dementia diagnosis. Also, if necessary, additional investigations were made for a diagnosis of probable dementia (i.e. EEG). All subjects underwent detailed neurpsychological investigation including MMSE, Blassed Daily Living Activity Test, Digit span, Counting, Abstract thinking, Clock Driving Test, Boston Naming Test, Word Learning Test, Word Memory Test, Word recognition Test, Visual Learning and Memory Test, Neuropsychiatric Inventory (NPI), Global Deterioration Scale (GDS) and CDR: Clinical Dementia Rating for diagnosis and grading dementia disorders. In order to exclude other causes of memory deficit, laboratory tests were performed, including whole chemistry of blood, B12, folate levels, thyroid function tests and sero- logical screens. Also, a differential diagnosis to distinguish $A D$ from other causes of dementia using a neuroimaging protocol with MRI or CT was performed. Some cases underwent standardised SPECT investigation if needed. Exclusion criteria were the presence of known inflammatory disorders, infectious, or immune diseases which possibly cause cognitive disturbances, overlapping syndromes (AD plus Vascular dementia, motor neuron disorders, etc.), comorbid neuropsychiatric disorders (epilepsy, previous known psychotic disorders, dependency, etc.), major head trauma, severe renal or hepatic failure, recent severe haemodynamic disturbance (decompensated heart failure, shock, acute myocardial ischemia, etc.) and the subject not accepting inclusion in the study.

\section{Genotyping determination}

DNA was extracted from peripheral blood leukocytes; PCR was performed in a $25-\mu \mathrm{L}$ volume with $100 \mathrm{ng}$ DNA, 100 $\mu \mathrm{m}$ dNTPs, $20 \mathrm{pmol}$ of each primer, $1.5 \mathrm{mM} \mathrm{MgCl}$, 1 x PCR buffer with (NH4)2SO $\mathrm{SO}_{4}$ (Fermentas, Vilnius, Lithuania), 10\% DMSO and $2 \cup$ Taq DNA polymerase (Fermentas, Vilnius, Lithuania). Amplification was performed on an automated Thermal Cycler (Techne Flexigene, Cambridge, UK). These genetic polymorphisms were determined by fragment separation at $120 \mathrm{~V}$ for $40-50$ minutes on a $3.5 \%$ agarose gel containing $0.5 \mathrm{mg} / \mathrm{mL}$ ethidium bromide. A 100-bp DNA Ladder (Fermentas Vilnius, Lithuania) was used as a size standard for each gel lane. The gel was visualised under UV light using a gel electrophoresis visualising system (Vilber Lourmat). PCRRFLP conditions for the G422A (rs6557634), C626G (rs20575) and A683C (rs20576) polymorphisms of the DR4 gene are shown in Table 1.

\section{Statistical Analysis}

The Hardy-Weinberg equilibrium was verified using the chi-square test and by estimating the expected genotype frequencies on the basis of the development of the square of the binomial for these polymorphisms. Allelic and genotypic distributions among the different groups were compared using the likelihood-ratio chi-square test or Fisher's exact test. Linkage disequilibrium was tested and haplotype analysis was used to evaluate the effect of the linked genes. Any frequencies smaller than 0.03 were ignored during analysis (18). Platform (http://analysis.bio-x.cn/myAnalysis.php) and SPSS 11.5 for Windows were used to perform statistical analysis.

\section{Results}

A power calculation analysis was performed using the Power for Genetic Association Analyses (PGA) software. Given the sample size of this study, we obtained a statistical power of $72 \%$. Patients with AD were well-matched with controls in terms of age $(p=0.57)$ and gender $(p=0.58)$. The patients with AD included in this study database were comprised of the patients with mean disease duration (min:, max: years). Details data of the patients are given in Table 2 .

We determined alleles and genotypes of rs6557634 and rs20575 and rs20576 polymorphism of the DR4 gene (Table 3 ). We observed significant differences in the genotypic distribution of the rs6557634 polymorphism for AD compared with controls $(p=0.03)$. Our data suggest that the GA geno- 
Table 1. PCR-RFLP conditions of DR4 gene polymorphisms

\begin{tabular}{|c|c|c|c|c|c|}
\hline Gene & Polymorphism & Primers & An. Temp. & RE & PCR products \\
\hline \multirow{6}{*}{ DR4 } & \multirow{2}{*}{ rs6557634 } & 5' ATCCTCTGGGAACTCTGTGG-3' & \multirow{2}{*}{$59^{\circ} \mathrm{C}$} & \multirow{2}{*}{ BseGl } & Allele G: 230bp \\
\hline & & 5'-ТАССАСТСССАССТTCACTGC-3', & & & Allele A:160bp, 70bp \\
\hline & \multirow{2}{*}{ rs20575 } & 5'-AAGGTCAAGGGACACGTCAGG-3' & \multirow{2}{*}{$58^{\circ} \mathrm{C}$} & \multirow{2}{*}{ Adel } & Allele C: $164 \mathrm{bp}, 56 \mathrm{bp}$ \\
\hline & & 5'-GCTTCTGTGGTTTCTTTTGAGG-3' & & & Allele G: 220bp \\
\hline & \multirow{2}{*}{ rs20576 } & 5'-ATCCCACCTGGCCAGCTTTCCA-3' & \multirow{2}{*}{$61^{\circ} \mathrm{C}$} & \multirow{2}{*}{ Taql } & Allele A: 110bp, $91 \mathrm{bp}$ \\
\hline & & 5'-AGACAGGAGTCTCGGGCTGCT-3' & & & Allele C: $201 \mathrm{bp}$ \\
\hline
\end{tabular}

type in rs6557634 could be a protective factor against AD. Also, no significant positive association was found between the polymorphisms rs20575 and rs20576 and AD ( $p=0.970$ and $p=0.495$, respectively).

The genotype distribution of the subjects was in line with Hardy-Weinberg equilibrium, which indicated that the samples were a representative group. We demonstrated that the genotypes of rs6557634, rs20575 and rs20576 of DR4 gene are in linkage disequilibrium with AD; the LD between rs6557634 and rs20575 is strong (LD Correlation, R:0.686986, D Prime:0.835465). Similarly, we found LD between rs20575 and rs20576 (LD Correlation, R:0.333014, D Prime:0.615691) and between rs6557634 and rs20576 of the DR4 gene (LD Correlation, R:0.465857, D Prime: 0.708228).

According to haplotype analysis of the DR4 gene for rs6557634, rs20575 and rs20576 polymorphisms, GCA* and GCC * haplotypes are potential risk factors for $A D\left(X^{2}=22.010\right.$ OR $[95 \% \mathrm{Cl}]=6.219[2.685 \sim 14.407], \mathrm{X}^{2}=1.530 \mathrm{OR}[95 \% \mathrm{Cl}]=$ 1.411 [0.817 2.440]). Also, we have determined that $A C A^{\star *}$, $\mathrm{GGC}^{\star \star}$ and $\mathrm{GGA}{ }^{\star \star}$ haplotypes could be protective factors against $A D\left(X^{2}=5.176\right.$ OR $[95 \% C l]=0.444(0.218 \sim 0.905]$, $X^{2}=17.491$ OR $[95 \% \mathrm{Cl}]=0.191(0.083 \sim 0.443], X^{2}=4.259$ OR $[95 \% \mathrm{Cl}]=0.562(0.325 \sim 0.975])$ (shown at Table 4).

\section{Discussion}

In this study, we have showed that the DR4 gene polymorphism rs6557634 may be important for $A D$. AD is the most common chronic neurodegenerative disorder; however, the role of TRAIL in AD pathogenesis is not clear. TRAIL is known to selectively induce apoptosis in many transformed cells but not in normal cells and recent developments imply that TRAIL should be considered as a fine-tuning regulator of the immune system (11). Cantarella et al. reported that neutralisation of the TRAIL death pathway protects the SHSY5Y neuronal cell line from $\beta$-amyloid toxicity (13). Recent studies point to activation of the extrinsic apoptotic pathway via death receptor 6 (DR6) in AD. Cleavage of APP in the b-secretase region and generation of an N-terminal APP fragment (NAPP) generate a death ligand for DR6. The activation of DR6 triggers CASP6 activation and axonal degeneration (16). Active caspase- 6 is present in the post-mortem brains of Huntington's and Alzheimer's disease subjects that do not yet display apoptotic morphology, which suggests a function distinct from its well-validated executioner role (8).

The molecular mechanisms of this effect are largely unknown; therefore, further evaluation of TRAIL signalling and
Table 2. Demographic characteristics of Alzheimer's disease patients

\begin{tabular}{|c|c|c|c|}
\hline \multirow[b]{2}{*}{ Clinical Variable } & \multicolumn{2}{|c|}{ Alzheimer's Disease } & \multirow{2}{*}{$\begin{array}{l}\text { Patients } \\
\text { Min- Max }\end{array}$} \\
\hline & Max score & Mean \pm SD & \\
\hline Disease Duration & - & & \\
\hline MMSE score & 30 & $22 \pm 2.4$ & $4-25$ \\
\hline DLAS & 23 & $14 \pm 3.1$ & $0-23$ \\
\hline Digit span-forward & 7 & $3 \pm 1.2$ & $0-6$ \\
\hline Digit span- backward & 7 & $2 \pm 4.8$ & $0-5$ \\
\hline Counting Score & 5 & $2 \pm 2.1$ & $0-5$ \\
\hline Abstract Thinking & 3 & $1 \pm 3.8$ & $0-3$ \\
\hline Word Learning Test & & $3 \pm 1.5$ & $0-6$ \\
\hline Word Memory Test & & $4 \pm 1.2$ & $0-8$ \\
\hline Word Recognition Test & & $3 \pm 4.2$ & $0-7$ \\
\hline Visual Learning Test & & $5 \pm 2.3$ & $0-11$ \\
\hline Visual Memory Test & & $4 \pm 3.1$ & $0-11$ \\
\hline Clock Driving Test score & 10 & $4 \pm 4.1$ & $0-10$ \\
\hline Boston Naming Test Score & 15 & $8 \pm 2.1$ & $0-15$ \\
\hline NPI- Total & 120 & $25 \pm 4.5$ & $0-74$ \\
\hline GDS (n, \%) & - & & \\
\hline Grade 3 & & $15(\% 21)$ & \\
\hline Grade 4 & & $7(\%$ 10.1) & \\
\hline Grade 5 & & $20(\% 30.5)$ & \\
\hline Grade 6 & & $14(\%$ 20.2) & \\
\hline Grade 7 & & $12(\%$ 18.2) & \\
\hline CDR & 3 & $1 \pm 2.5$ & $0-3$ \\
\hline
\end{tabular}

CDR: Clinical Dementia Rating; DLAS: Daily Living Activity Scale; MMSE:Mini Mental State Examination; NPI: Neuropsychiatric Inventory

TRAIL receptors in AD could be necessary. The sequential events leading to the demise of neurons in AD have been extensively studied, yet the precise cause of neuronal death in $A D$ is not well understood. Explaining the signalling mechanisms that underlie neuronal apoptosis during $A D$ is therefore critical for unravelling the pathophysiology of the disease. SNPs reside next to the DR4 ligand-binding ectodomain and 
Table 3. Genotype and allele frequencies of rs6557634, rs20575 and rs20576 polymorphisms of the DR4 gene in AD and control groups

\begin{tabular}{|c|c|c|c|c|c|}
\hline \multirow[b]{2}{*}{ rs6557634 } & \multicolumn{2}{|c|}{ Genotypes } & \multicolumn{3}{|c|}{ Alleles } \\
\hline & $\begin{array}{c}\text { Controls } \\
\text { n (\%) }\end{array}$ & $\begin{array}{l}\text { Patients } \\
\text { n (\%) }\end{array}$ & & $\begin{array}{c}\text { Controls } \\
\text { n (\%) }\end{array}$ & $\begin{array}{c}\text { Patients } \\
\text { n (\%) }\end{array}$ \\
\hline GG & 21 (26.9 \%) & 27 (40.3 \%) & G Allele & 82 (52.5 \%) & 96 (62.5\%) \\
\hline GA & 40 (51.3 \%) & 22 (32.8 \%) & & & \\
\hline AA & 17 (21.8 \%) & 18 (26.9\%) & A Allele & 74 (47.5 \%) & $58(37.5 \%)$ \\
\hline rs20575 & $\begin{array}{c}\text { Controls } \\
\text { n (\%) }\end{array}$ & $\begin{array}{c}\text { Patients } \\
\text { n (\%) }\end{array}$ & & $\begin{array}{c}\text { Controls } \\
\text { n (\%) }\end{array}$ & $\begin{array}{c}\text { Patients } \\
\text { n (\%) }\end{array}$ \\
\hline GG & 21 (26.9\%) & 20 (29.4 \%) & G Allele & 88 (56.4 \%) & 80 (58.8 \%) \\
\hline GC & 46 (59.0 \%) & 40 (58.8 \%) & & & \\
\hline $\mathrm{CC}$ & 11 (14.1\%) & 8 (11.8 \%) & C Allele & 68 (43.6 \%) & 56 (41.2 \%) \\
\hline rs20576 & $\begin{array}{c}\text { Controls } \\
n(\%)\end{array}$ & $\begin{array}{c}\text { Patients } \\
\text { n (\%) }\end{array}$ & & $\begin{array}{c}\text { Controls } \\
\text { n (\%) }\end{array}$ & $\begin{array}{c}\text { Patients } \\
\text { n (\%) }\end{array}$ \\
\hline AA & 44 (56.4 \%) & 45 (66.2 \%) & A Allele & $113(72.4 \%)$ & 109 (80.1\%) \\
\hline$A C$ & 25 (32.1 \%) & 19 (27.9 \%) & & & \\
\hline CC & 9 (11.5\%) & 4 (5.9 \%) & C Allele & 43 (27.6 \%) & $27(19.9 \%)$ \\
\hline
\end{tabular}

Table 4. Haplotype distributions for the rs6557634, rs20575 and rs20576 polymorphisms in the DR4 gene in control and AD groups ( $n=$ Number of individuals)

\begin{tabular}{|lcccc|}
\hline $\begin{array}{l}\text { Haplotypes } \\
\text { rs6557634, rs20575 } \\
\text { and rs20576 }\end{array}$ & $\begin{array}{c}\text { Controls } \\
\mathbf{n}(\%)\end{array}$ & $\begin{array}{c}\text { Patients } \\
\mathbf{n}(\%)\end{array}$ & $\mathbf{X}^{\mathbf{2}}$ & Odds Ratio [95\% Cl] \\
\hline A C A** & $28.40(0.182)$ & $12.43(0.093)$ & 5.176 & $0.444[0.218 \sim 0.905]$ \\
A C C & $4.24(0.027)$ & $0.00(0.000)$ & - & - \\
A G A & $7.36(0.047)$ & $32.24(0.241)$ & 22.010 & $6.219[2.685 \sim 14.407]$ \\
G C A & $31.47(0.202)$ & $36.14(0.270)$ & 1.530 & $1.411[0.817 \sim 2.440]$ \\
G C C* & $3.89(0.025)$ & $6.43(0.048)$ & 1.025 & $1.918[0.533 \sim 6.905]$ \\
G G A** & $45.77(0.293)$ & $26.19(0.195)$ & 4.259 & $0.562[0.325 \sim 0.975]$ \\
G G C** & $34.87(0.224)$ & $7.24(0.054)$ & 17.491 & $0.191[0.083 \sim 0.443]$ \\
A G C & $0.00(0.000)$ & $13.33(0.099)$ & 15.829 & - \\
\hline$*$ * haplotype might be risk factor for AD, **: haplotype might be protective factor against AD & \\
\multicolumn{4}{r}{} \\
\hline
\end{tabular}

may affect TRAIL binding, and as a result apoptotic signalling (19). However, the cell source of TRAIL in CNS is not clear. TRAIL is absent in the normal brain, but is induced under pathological conditions; CNS neurons usually do not express TRAIL (13). Nikolaev et al. found that that APP and DR6 are components of a neuronal self-destruction pathway, and suggest that an extracellular fragment of APP, acting via DR6 and caspase-6, contributes to Alzheimer's disease (16). Death receptors belong to the TNF superfamily of receptors, and each activates the apical caspase- 8 by first recruiting the adapter proteins FADD (Fas-associated death domain) and/or TRADD (TNF receptor-associated death domain). As a consequence, death receptors activate the caspases in the apoptotic path and participate in the signal-conduction process (20).
The TRAIL/TRAIL receptor system has recently been implicated as a disease activation marker in cancer $(21,22)$. Lack of tumor necrosis factor related apoptosis-inducing ligand but presence of its receptors in the human brain. The $\beta$-amyloid protein and ischemia were found to induce TRAIL expression in neuron-derived neuroblastoma cells (19). Genc et al. (23) previously demonstrated that TRAIL is expressed in murine microglia and the expression is increased following immune activation by IFN-c and LPS. Many other studies have previously shown that rs6557634, rs20575 and rs20576 in the DR4 gene are important for cancer, asthma and Behçet's disease (24-26). Also, an association between TRAIL gene polymorphisms and multiple sclerosis was shown (27); however, to the best of our 
knowledge, there has not been any study of DR4 gene polymorphisms and AD.

Our study suggested the possible contribution of DR4 gene polymorphisms to AD. We found that there is a significant relationship between the rs6557634 polymorphism of the DR4 gene and AD. Previously, Genç et al. (23) did not find any significant difference in TRAIL mRNA in the PBMCs of patients with $A D$, but they indicated that TRAIL serum level decreases in the late stage of disease. Our study confirms the study performed by Genç et al. (23). When considered from this point of view, it may be assumed that the rs6557634 polymorphism of DR4 may important for Alzheimer's patients. However, this must be confirmed by expression studies of the DR4 gene in Alzheimer's disease.

In conclusion, these results showed the association of genetic variants of DR4 with $A D$. Further studies may be done on various polymorphisms belonging to DR4 receptors. The relationship of DR4 with Alzheimer's disease will be manifested more precisely if polymorphisms of the DR4 gene, gene expression and TRAIL protein levels in serum are analysed and evaluated together in a larger group of patients.

Ethics Committee Approval: Ethics committee approval was received for this study from Mersin University Faculty of Medicine Medical Ethics Committee (2006).

Informed Consent: Written informed consent was received from the participants of this study.

Peer-review: Externally peer-reviewed.

Author contributions: Concept - T.G.E., A.Ö., M.E.E.; Design T.G.E., A.Ö., O.Ö.Y., S.K., M.E.E.; Supervision - T.G.E., A.Ö., M.E.E.; Resource-T.G.E., A.Ö., O.Ö.Y., S.K., M.E.E.; Materials - A.Ö., O.Ö.Y.; Data Collection\&/or Processing - T.G.E., A.Ö., O.Ö.Y., M.E.E.; Analysis\&/or Interpretation - T.G.E., A.Ö., O.Ö.Y., S.K., M.E.E.; Literature Search - T.G.E., A.Ö., M.E.E.; Writing - T.G.E., A.Ö., O.Ö.Y., S.K., M.E.E.; Critical Reviews: A.Ö., M.E.E.

Conflict of Interest: The authors declared no conflict of interest.

Financial Disclosure: The authors declared no financial disclosure.

\section{References}

1. Gatz M, Reynolds CA, Fratiglioni L, Johansson B, Mortimer JA, Berg $S$, et al. Role of genes and environments for explaining Alzheimer disease. Arch Gen Psychiatry 2006;63:168-74. [CrossRef]

2. Selkoe DJ. Alzheimer's disease: genes, proteins, and therapy. Physiol Rev 2001;81:741-66.

3. Suzuki T, Araki Y, Yamamoto T, Nakaya T. Trafficking of Alzheimer's disease-related membrane proteins and its participation in disease pathogenesis. J Biochem 2006;139:949-55. [CrossRef]

4. Sorrentino G, Bonavita V. Neurodegeneration and Alzheimer's disease: the lesson from tauopathies. Neurol Sci 2007;28:63-71. [CrossRef]

5. Ashkenazi A, Dixit VM. Death receptors: signaling and modulation. Science 1998;281:1305-8. [CrossRef]

6. Ashkenazi A, Dixit VM. Apoptosis control by death and decoy receptors. Curr Opin Cell Biol 1999;11:255-60. [CrossRef]

7. Wu CK, Thal L, Pizzo D, Hansen L, Masliah E, Geula C. Apoptotic signals within the basal forebrain cholinergic neurons in Alzheimer's disease. Exp Neurol 2005;195:484-96. [CrossRef]

8. Graham RK, Ehrnhoefer DE, Hayden MR. Caspase-6 and neurodegeneration. Trends Neurosci 2011:34;646-56. [CrossRef]

9. Jin Z, El-Deiry WS. Overview of cell death signaling pathways. Cancer Biol Ther 2005;4:139-63. [CrossRef]
10. Kuwano R, Miyashita A, Arai H, Asada T, Imagawa M, Shoji M, et al. Dynamin-binding protein gene on chromosome $10 q$ is associated with late-onset Alzheimer's disease. Hum Mol Genet 2006;15:2170-82. [CrossRef]

11. Anel A, Bosque A, Naval J, Pineiro A, Larrad L, Alava MA, et al. Apo2L/TRAIL and immune regulation. Front Biosci 2007;12: 2074-84. [CrossRef]

12. Lukiw WJ, Bazan NG. Survival signalling in Alzheimer's disease. Biochem Soc Trans 2006:34:1277-82. [CrossRef]

13. Cantarella G, Uberti D, Carsana T, Lombardo G, Bernardini R, Memo M. Neutralization of TRAlL death pathway protects human neuronal cell line from $\beta$-amyloid toxicity. Cell Death Differ 2003;10:134-41. [CrossRef]

14. Uberti D, Cantarella G, Facchetti F, Cafici A, Grasso G, Bernardini $\mathrm{R}$, et al. TRAIL is expressed in the brain cells of Alzheimer's disease patients. Neuroreport 2004;15:579-581. [CrossRef]

15. Uberti D, Ferrari-Toninelli G, Bonini SA, Sarnico I, Benarese M, Pizzi $\mathrm{M}$, et al. Blockade of the tumor necrosis factor-related apoptosis inducing ligand death receptor DR5 prevents beta-amyloid neurotoxicity. Neuropsychopharmacology 2007;32:872-80. [CrossRef]

16. Nikolaev A, McLaughlin T, O'Leary DD, Tessier-Lavigne M. APP binds DR6 to trigger axon pruning and neuron death via distinct caspases. Nature 2009;19:981-9. [CrossRef]

17. McKhann G, Drachman D, Foltein M, Katzman R, Price D, Stadlen EM. Clinical diagnosis of Alzheimer's disease: report of the NINCDS-ADRDA Work Group under the auspices of Department of Health and Human Services Task Force on Alzheimer's disease. Neurology 1984;34:939-44. [CrossRef]

18. Li Z, Zhang Z, He Z. A partition-ligation-combination-subdivision EM algorithm for haplotype inference with multiallelic markers: update of the SHEsis (http://analysis.bio-x.cn). Cell Res 2009;19:519-23. [CrossRef]

19. Dörr J, Bechmann I, Waiczies S, Aktas O, Walczak H, Krammer PH, et al. Lack of tumor necrosis factor-related apoptosis-inducing ligand but presence of its receptors in the human brain. J Neurosci 2002;15:22-4.

20. Nitsch R, Bechmann I, Deisz RA, Haas D, Lehmann TN, Wendling $U$, et al. Human brain-cell death induced by tumournecrosis- factor-related apoptosis-inducing ligand (TRAIL). Lancet 2000;356: 827-8. [CrossRef]

21. Koksal IT, Sanlioglu AD, Karacay B, Griffith TS, Sanlioglu S. Tumor necrosis factor-related apoptosis inducing ligand-R4 decoy receptor expression is correlated with high Gleason scores, prostatespecific antigen recurrence, and decreased survival in patients with prostate carcinoma. Urol Oncol 2008;26:158-65. [CrossRef]

22. Sanlioglu AD, Korcum AF, Pestereli E, Erdogan G, Karaveli S, Savas $B$, et al. TRAIL death receptor- 4 expression positively correlates with the tumor grade in breast cancer patients with invasive ductal carcinoma. Int J Radiat Oncol Biol Phys 2007;69:716-23. [CrossRef]

23. Genc S, Egrilmez MY, Yaka E, Cavdar Z, lyilikci L, Yener G, et al. TNF-related apoptosis-inducing ligand level in Alzheimer's disease. Neurol Sci 2009;30:263-7. [CrossRef]

24. Isi H, Erdal ME, Akdeniz S, Oral D, Ay Ol, Tekes S, et al. The Tumor necrosis factor- $\alpha$ (TNF-A) gene $-308 \mathrm{G} / \mathrm{A}$ polymorphism and the tumor necrosis factor-related apoptosis-inducing ligand (TRAIL) gene polymorphisms in Behcet's disease. Biotechnol \& Biotechnol 2010;24:3.

25. Isi H, Oral D, Yildiz T, Ates G, Sinir C, Ay Ol, et al. The tumor necrosis factor- $\alpha-308 \mathrm{G} / \mathrm{A}$ polymorphism and the tumor necrosis factor-related apoptosis-inducing ligand polymorphisms, in asthmatic patients and healthy subjects. Biotechnol \& Biotechnol 2010;24:1.

26. Chen B, Liu S, Wang XL, Xu W, Li Y, Zhao WH, et al. TRAIL-R1 polymorphisms and cancer susceptibility: an evidence-based metaanalysis. Eur J Cancer 2009;45:2598-605. [CrossRef]

27. Kikuchi S, Miyagishi R, Fukazawa T, Yabe I, Miyazaki Y, Sasaki H. TNF-related apoptosis inducing ligand (TRAIL) gene polymorphism in Japanese patients with multiple sclerosis. J Neuroimmunol 2005;167:170-4. [CrossRef] 